\title{
Enhancement of alkali-activated slag cement concretes crack resistance for mitigation of steel reinforcement corrosion
}

\author{
Pavlo Krivenko, Oleh Petropavlovskyi, Oleksandr Kovalchuk, Igor Rudenko, and Oleksandr Konstantynovskyi*
}

Kyiv National University of Construction and Architecture, Scientific Research Institute for Binders and Materials, 31 Povitroflotskyi Ave., Kyiv, 03037, Ukraine

\begin{abstract}
The paper is devoted to mitigation of steel reinforcement corrosion in alkali-activated slag cement (further, AASC) concretes, based on soluble sodium silicates (further, SSS's), obtained from high consistensy concrete mixes. Enhancement of AASC fine concretes crack resistance due to modification by complex shrinkage-reducing additives (further, SRA's) based on surfactants and trisodium phosphate $\mathrm{Na}_{3} \mathrm{PO}_{4} \cdot 12 \mathrm{H}_{2} \mathrm{O}$ (further, TSP) was proposed for mitigation of steel reinforcement corrosion. SSS's were presented by sodium metasilicate (silica modulus 1.0, dry state) and water glass (silica modulus 2.9, density $1400 \mathrm{~kg} / \mathrm{m}^{3}$ ). In case of sodium metasilicate the application of SRA composition "ordinary portland cement clinker - TSP - sodium lignosulphonate - sodium gluconate" provides enhancement of crack resistance starting from early age structure formation with restriction of drying shrinkage from 0,984 to $0,713 \mathrm{~mm} / \mathrm{m}$ after $80 \mathrm{~d}$. The effect is caused by reduction of water and by higher volume of crystalline hydrates. In turn, SRA presented by compositions "TSP - glycerol" and "TSP - glycerol - polyacrylamide" provide enhancement of AASC fine concretes fracture toughness during late structure formation with increasing ratio of tensile strength in bending to compressive strength up to $37-49 \%$ if compare with the reference AASC when water glass is used.
\end{abstract}

\section{Introduction}

The actuality of green materials implementation is due to their conformity with modern tendencies of building industry development in the part of efficient consumption of raw materials and energy resources, responsible attitude to ecology of the environment, while ensuring high quality, functionality and durability of building materials. Thus eco-efficient composite cements, based on slag, zeolite, fly-ash, limestone as well as microsilica, ensure high early strength of mortars $[1,2]$. Application of a highly dispersed chalk as an additive in these cements increases strength, waterproof and freeze-thaw resistance of concretes [3, 4$]$.

Alkali-activated slag cement (further, AASC) are the most perspective environmentally friendly one in view of the modern tendencies of sustainable development. The ecological benefits of AASC's are caused by reduction of $\mathrm{CO}_{2}$ emission while consumption of byproducts as well as waste products [5, 6, 7]. AASC mortars and concretes are characterized by increased strength [8, 9], heat resistance $[10,11]$, corrosion resistance $[12,13]$, freeze-thaw resistance $[14,15]$ and waterproof [16] in comparison with analogues based on traditional clinker cements.

Thus, AASC's are effective for strategic construction objects with special destination (fortifications, sea ports, bridge foundations, tunnels, etc.), which must be exploited in various aggressive mediums. AASC based on soluble sodium silicates (further, SSS) is the most interesting type, first of all due to comparative strength benefits. This fact is relevant for special concretes.

High durability of AASC reinforced concretes obtained from harsh (low consistency) concrete mixes was already proved by long-term exploiting experience [17-21]. However, the modern requirements to high consistency fresh concretes are governed by practice. This way the disturbance of reinforcement passive state can be caused by changes in hardened concrete structure. The means for protection of reinforcement in such AASC concretes must be developed. One of decisions is the enhancement of crack resistance during all stages of service life cycle.

AASC concretes along with high strength are characterized by increased drying shrinkage and fracturing $[22,23,24]$ due to high content of gel during initial structure formation. The drying shrinkage causes heterogeneous structure of concrete during further structure formation and as a result the unstable characteristics of artificial stone [25].

There are number of means to prevent fracturing, for example fiber reinforcement of concrete [26]. It's also well known, that surfactants allow regulating consistency while ensuring high strength of concrete. Diminution of drying shrinkage is a result of decreased water. Most of surfactants are ineffective for AASC and therefore the principles for their choice were proposed $[27,28]$. The maximum water-reducing effect in this

Corresponding author: alexandrkp@gmail.com 
case can be provided by sodium lignosulfonate [29], sodium gluconate [30], polyhydric alcohols [27], etc. Triatomic alcohol glycerol and polyacrylamide are the most perspective modifiers of AASC's based on water glass. These admixtures bind surface groups of silicic acid oligomers by means of hydrogen links while ensuring high strength, waterproof and elasticity of AASC mortars and concretes [31, 32, 33].

Another mean for drying shrinkage mitigation is complex application of admixtures and additives. It was shown the effectiveness of salts-electrolytes, like $\mathrm{Na}_{2} \mathrm{SO}_{4}$ [34], and by-pass cement kiln dust, which typical components are free $\mathrm{CaO}$ and salts $\left(\mathrm{KCl}, \mathrm{NaCl}, \mathrm{K}_{2} \mathrm{SO}_{4}\right.$, $\mathrm{Na}_{2} \mathrm{SO}_{4}, \mathrm{CaSO}_{4}, \mathrm{~K}_{2} \mathrm{CO}_{3}, \mathrm{Na}_{2} \mathrm{CO}_{3}, \mathrm{CaCO}_{3}$, etc.) [35, 36]. Trisodium phosphate $\mathrm{Na}_{3} \mathrm{PO}_{4} \cdot 12 \mathrm{H}_{2} \mathrm{O}$ (further, TSP) is well-known retarder of AASC setting time [37, 38]. TSP also ensures effect of water glass stabilizer to prevent early coagulation while interaction with slag in AASC [39]. Moreover, TSP can be used as inhibitor of steel reinforcement corrosion due to formation of chemical stable products like hydroxyapatite $\mathrm{Ca}_{10}\left(\mathrm{PO}_{4}\right)_{6}(\mathrm{OH})_{2}$ [37] with formation of a dense protective film on metal surface [40, 41], increasing polarization resistance of rebar $[42,43]$ as well as decrease of capillary pore network with time [44].

The fundamentals of mineralogy and chemistry can give some explanations concerning effect of the mentioned compounds on the structure of AASC stone, namely about isomorphism with replacing of silicate or aluminate anion, formation of solid solutions or additional crystalline formations, which reduce the proper deformations [45]. These compounds can be used as complex modifiers of AASC.

Increasing of AASC's crack resistance in consequence of drying shrinkage mitigation can also be accomplished by increasing crystallinity of hydrated phases when using high-calcium additives such as ordinary portland cement clinker (further, OPC clinker) $[18,46]$ or lime $[47,48]$.

The above results allows to predict increasing of AASC crack resistance due to complex shrinkagereducing additives (further, SRA's) in the system "additives - surfactants". Specified method was proposed for mitigation of steel reinforcement corrosion in high consistency AASC concretes, modified with SRA's based on salts-electrolytes, i.e. $\mathrm{Na}_{2} \mathrm{SO}_{4}$ and $\mathrm{NaNO}_{3}[24,49,50]$. The effectiveness of these SRA's was explained by their co-acting in crystallization processes, alteration of porous structure as well as morphology of hydrated phases.

The aim of this research was to ensure crack resistance of AASC concretes, based on SSS and plasticized by SRA's, for mitigation of steel reinforcement corrosion during all stages of structure formation.

\section{Raw Materials and Methods}

Five compositions of AASC based on SSS were used: - \# 1 - the reference AASC based on sodium metasilicate (ground granulated blast furnace slag (further, GBFS) - 88.20\%, sodium metasilicate - 11.80 $\%\left(3.91 \%\right.$ by $\left.\mathrm{Na}_{2} \mathrm{O}\right)$ );

- \# 2 - AASC based on sodium metasilicate, modified by SRA composition "OPC clinker - TSP - sodium lignosulphonate - sodium gluconate" (GBFS - 83.80\%; sodium metasilicate $-11.20 \%\left(3.91 \%\right.$ by $\left.\mathrm{Na}_{2} \mathrm{O}\right)$; SRA $-5 \%)$

- \# 3 - the reference AASC based on sodium water glass (GBFS - $71.74 \%$; water glass, modified by TSP - 28.26 $\%$;

- \# 4 - AASC based on sodium water glass, modified by SRA composition "TSP - glycerol" (GBFS - $71.65 \%$; water glass, modified by TSP $-25.65 \%$, glycerol -2.70 $\%)$;

- \# 5 - AASC based on sodium water glass, modified by SRA composition "TSP - glycerol - polyacrylamide" (GBFS - $71.65 \%$; water glass, modified by TSP - 25.65 $\%$, glycerol $-2.69 \%$, polyacrylamide $-0.01 \%$ ).

GBFS, basicity modulus $=1.1$, content of glass phase $=84 \%$, specific surface $=450 \mathrm{~m}^{2} / \mathrm{kg}$ (by Blaine), was used as AASC aluminosilicate component.

SSS were used as AASC alkaline components:

- five-water sodium metasilicate $\left(\mathrm{Na}_{2} \mathrm{SiO}_{3} \cdot 5 \mathrm{H}_{2} \mathrm{O}\right)$, dry state;

- sodium water glass, modulus $\mathrm{M}_{\mathrm{s}}=2.9$, density= $1400 \mathrm{~kg} / \mathrm{m}^{3}$.

Surfactants in SRA's were presented by: - sodium lignosulphonate (further, LST) according to CAS 8061-51-6 (pH $\geq 8.5)$ and sodium gluconate according to CAS 527-07-1 (for AASC's based on sodium metasilicate);

- glycerol according to CAS 56-81-5 and polyacrylamide according to CAS 9003-05-8 (for AASC based on water glass).

Additives in SRA's were presented by:

- OPC clinker $\left(\mathrm{CaO}-66.15 \% ; \mathrm{SiO}_{2}-22.61 \% ; \mathrm{Al}_{2} \mathrm{O}_{3}\right.$ $5.29 \% ; \mathrm{Fe}_{2} \mathrm{O}_{3}-3.93 \% ; \mathrm{MgO}-0.84 \% ; \mathrm{Na}_{2} \mathrm{O}-0.15 \%$, $\left.\mathrm{K}_{2} \mathrm{O}-0.98 \%, \mathrm{SO}_{3}-0.50 \%\right)$, specific surface= $450 \mathrm{~m}^{2} / \mathrm{kg}$ (by Blaine);

- $\mathrm{Na}_{3} \mathrm{PO}_{4} \cdot 12 \mathrm{H}_{2} \mathrm{O}$ (TSP) according to CAS № 7601-54-9.

The content of TSP was accepted experimentally while providing allowable initial setting time (not less 15-20 $\mathrm{min}$ ). TSP was dissolved in water glass to provide density $=1400 \mathrm{Kg} / \mathrm{m}^{3}$.

Normal consistency of cement pastes and setting time were determined according to the national standard of Ukraine DSTU B V.2.7-185:2009.

The standard quartz sand in accordance with EN 1961 was used as a fine aggregate to determine strength and proper deformations of AASC concrete.

Cement pastes and fine concrete mixes were prepared in mixer Hobart type.

Water-reducing effect of SRA's was evaluated by decreasing $\mathrm{W} / \mathrm{C}$ ratio in AASC/sand mixes (1:3) with slump flow $=106-115 \mathrm{~mm}$ on flow table according to the national standard of Ukraine DSTU B V.2.7-187:2009. The strength and proper deformations of AASC fine concrete were determined on specimens 40x40x160 mm. After manufacturing and hardening in forms with an insulated surface for 1 day, the samples were stored for $7 \mathrm{~d}$ under the normal conditions $\left(\mathrm{t}=20 \pm 2{ }^{\circ} \mathrm{C}\right.$, R.H. $=95 \pm 5 \%$ ). Then the samples were stored over 
saturated solution of potassium carbonate $\left(\mathrm{NH}_{4} \mathrm{NH}_{3}\right)$ at $\mathrm{t}=20 \pm 2{ }^{\circ} \mathrm{C}$ till the control age. The length of samples after $1 \mathrm{~d}$ was taken as the initial one (zero) in calculations.

Analysis of elastic-deformed state of AASC concretes under load was realized by bending test while determination of deformations up to destruction of samples (Fig. 1). Fracture toughness was estimated by the values of tensile strength in bending to compressive strength ratio. This method allows to determine effect of cement composition as well as structural features of cement on the values of deformation and destruction [51].

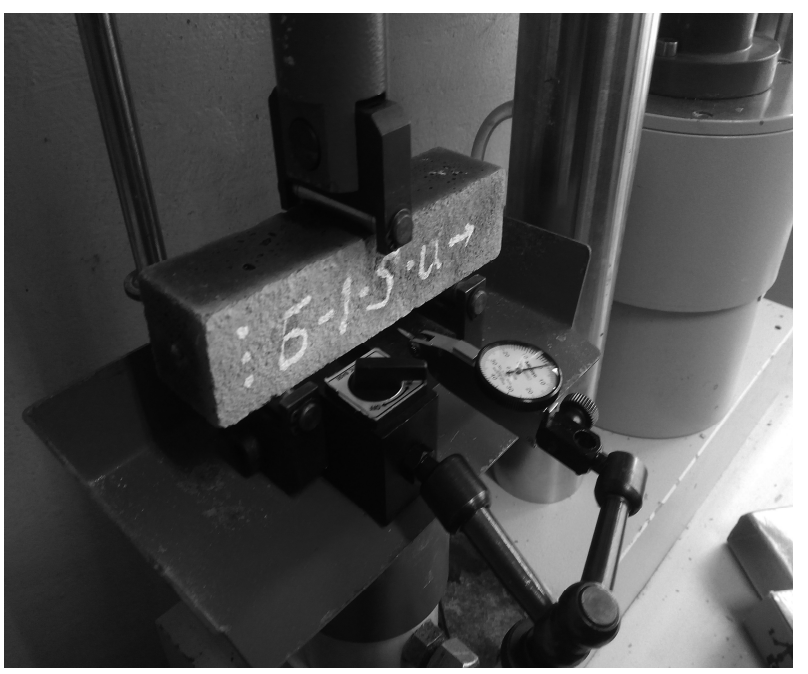

Fig. 1. Testing of samples under load.

Research of microstructure of artificial stone was carried out by differential-thermal analysis (DTA) and electronic microscope with micro analyzer.

\section{Results and discussion}

Effect of SRA's in the system "additives - surfactants" on crack resistance of AASC fine concrete (further, concrete) are shown on examples.

\subsection{Enhancement of crack resistance of alkali- activated slag cement concrete based on sodium metasilicate}

Characteristics of the reference AASC (without SRA): normal consistency of cement pastes $-21.67 \%$, initial setting time $-45 \mathrm{~min}$, final setting time $-45 \mathrm{~min}$. The tensile strength in bending / compressive strength of AASC concrete $(\mathrm{W} / \mathrm{C}$ ratio $=0.29)$ : $5.04 / 28.8 \mathrm{MPa}$ (2 d), 6.1 / 40.0 MPa (7 d) and 7.5 / 50.3 MPa (28 d).

Effect of SRA composition "OPC clinker - TSP LST - sodium gluconate" on drying shrinkage of AASC concrete was researched (Fig. 2). The reference AASC concrete is characterized by high drying shrinkage during the initial structure formation. SRA composition "OPC clinker - TSP - LST - sodium gluconate" ensures formation of AASC concrete with preferable structure and mitigation of drying shrinkage from 0,984 down to $0,713 \mathrm{~mm} / \mathrm{m}$ after $80 \mathrm{~d}$.

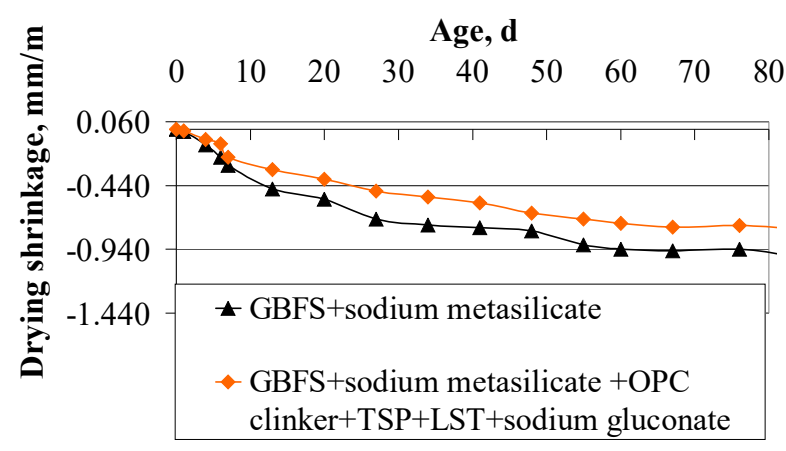

Fig. 2. Drying shrinkage of alkali-activated slag cement fine concrete.

SRA provides deceleration of AASC setting time as well. For example, SRA based on TSP provides prolongation of initial setting time from 45 up to $55 \mathrm{~min}$ and final setting time from 60 to $68 \mathrm{~min}$. Increasing strength of modified AASC concrete regarding to the reference one while decreasing $\mathrm{W} / \mathrm{C}$ ratio from 0.29 to 0.27 was fixed. The tensile strength in bending / compressive strength of the modified AASC concrete: 6.6 / $30.2 \mathrm{MPa}$ (2d), 6.4 / 41.2 MPa (7 d) i 10.2 / 47.8 $\mathrm{MPa}(28 \mathrm{~d})$.

The enhancement of AASC concrete properties can be provided not only by water-reducing effect of SRA, but also due to effect on further structure formation. The features of AASC structure, modified by SRA, were fixed by DTA (Fig. 3) and electronic microscopy (Fig. 4, 6) as well as by microzond analysis (Fig. 5, 7).

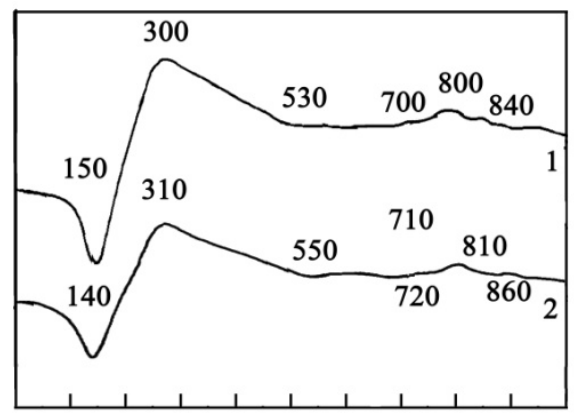

100200300400500600700800900

Fig. 3. DTA results of alkali-activated slag cement hydrated during $28 \mathrm{~d}$ : 1 -reference; 2 - modified by shrinkage-reducing admixture.

According to DTA, the phase composition of hydrated AASC in absence of SRA (Fig. 3) is represented low-calcium hydrosilicates $\mathrm{CSH}(\mathrm{B})$. The endothermic effect at $\mathrm{t}=150{ }^{\circ} \mathrm{C}$ is determined by their dehydration and exothermic effects at $\mathrm{t}=840{ }^{\circ} \mathrm{C}$ are determined by recrystallization into wollastonite. Endothermic effects at $\mathrm{t}=150$ and $700{ }^{\circ} \mathrm{C}$ (dehydration) and exothermic effect at $\mathrm{t}=800^{\circ} \mathrm{C}$ confirm formation of slightly crystallized calcium hydrosilicates like gyrolite $2 \mathrm{CaO} \cdot 3 \mathrm{SiO}_{2} \cdot 2 \mathrm{H}_{2} \mathrm{O}$. Slightly crystallized sodium hydroaluminosilicates like gmelinite $\left(\mathrm{Na}_{2} \mathrm{Ca}\right) \cdot \mathrm{Al}_{2} \mathrm{Si}_{4} \cdot \mathrm{O}_{12} \cdot 6 \mathrm{H}_{2} \mathrm{O}$ (endothermic effect at 
$\mathrm{t}=530^{\circ} \mathrm{C}$ ) are formed in hydration products besides hydrosylicates.

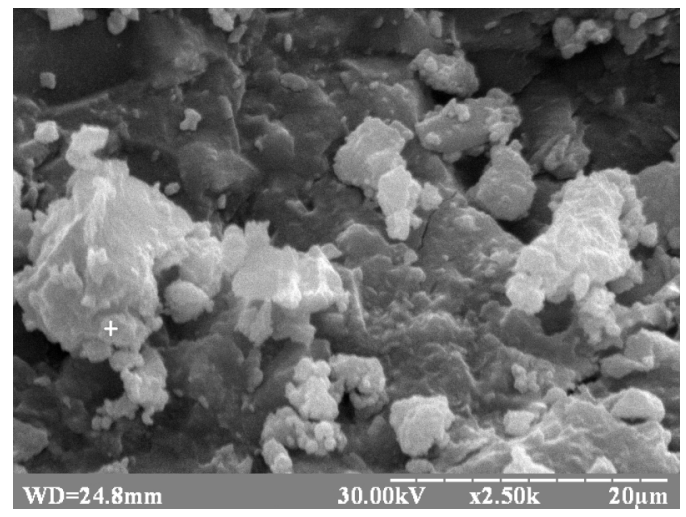

Fig. 4. SEM images of the reference alkali-activated slag cement after $28 \mathrm{~d}$ of hydration.

According to electron microscopy (Fig.4), gel-like calcium hydrosilicates ( $\left.\mathrm{CSH}(\mathrm{B}), 2 \mathrm{CaO} \cdot 3 \mathrm{SiO}_{2} \cdot 2 \mathrm{H}_{2} \mathrm{O}\right)$ and globular formations of sodium hydroaluminosilicate $\left(\left(\mathrm{Na}_{2} \mathrm{Ca}\right) \cdot \mathrm{Al}_{2} \mathrm{Si}_{4} \cdot \mathrm{O}_{12} \cdot 6 \mathrm{H}_{2} \mathrm{O}\right)$ are identified in the reference AASC (Fig. 5).

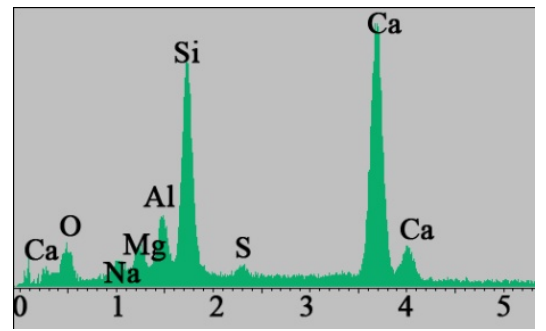

Fig. 5. Probe analysis results of the reference alkali-activated slag cement after $28 \mathrm{~d}$ of hydration.

Structure of the modified AASC is represented by hydrates with a higher crystallization in comparison with the reference AASC (Fig. 3). Displacement of exothermic effect from $\mathrm{t}=840$ to $850{ }^{\circ} \mathrm{C}$ is evidence of low-calcium hydrosilicates $\mathrm{CSH}(\mathrm{B})$ with higher crystallinity. Displacement of endothermic effect to higher temperature $\left(\mathrm{t}=550{ }^{\circ} \mathrm{C}\right)$ as well as exothermic effect at $\mathrm{t}=915{ }^{\circ} \mathrm{C}$ ensure formation of gmelinite $\left(\mathrm{Na}_{2} \mathrm{Ca}\right) \cdot \mathrm{Al}_{2} \mathrm{Si}_{4} \cdot \mathrm{O}_{12} \cdot 6 \mathrm{H}_{2} \mathrm{O}$ with a higher degree of crystallization.

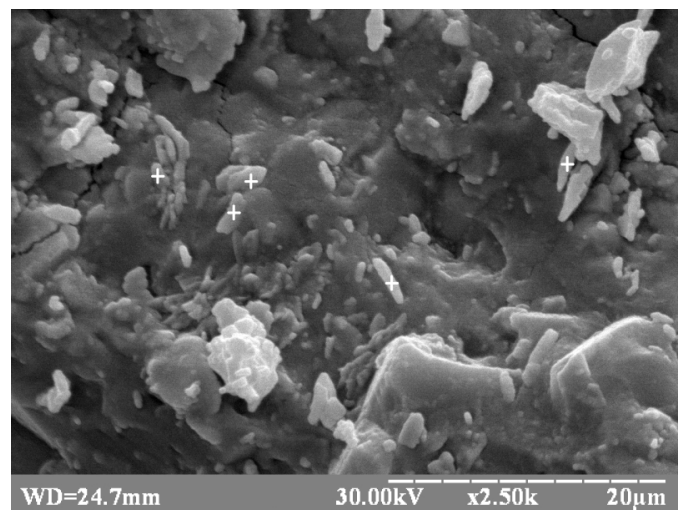

Fig. 6. SEM images of alkali-activated slag cement, modified by shrinkage-reducing admixture, after $28 \mathrm{~d}$ of hydration.

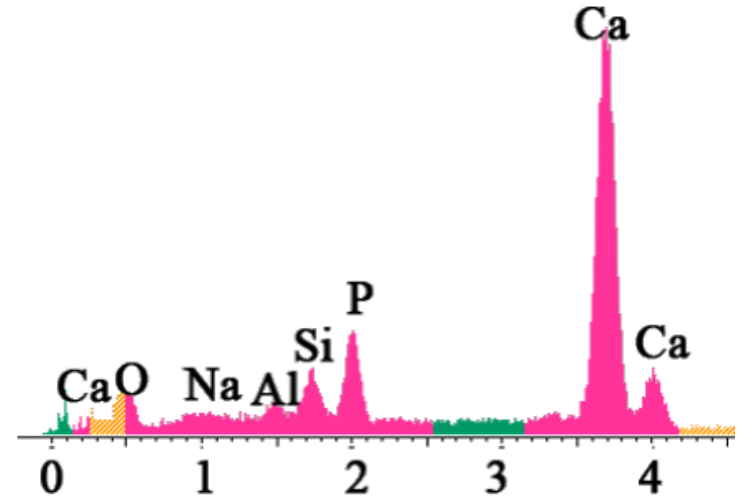

Fig. 7. Probe analysis results of alkali-activated slag cement, modified by shrinkage-reducing admixture, after $28 \mathrm{~d}$ of hydration.

The microstructure of modified AASC was investigated. The data indicate hydrosilicates and hydroaluminates with a higher degree of crystallization (Fig. 6) as well as thin plate pyramidal cristalls of hydroxyapatite $\mathrm{Ca}_{10}\left(\mathrm{PO}_{4}\right)_{6}(\mathrm{OH})_{2}$ [37] (Fig. 7).

\subsection{Enhancement of crack resistance of alkali- activated slag cement concretes based on sodium water glass}

The effect of SRA based on TSP and surfactants on enhancement of crack resistance of AASC mortars based on sodium water glass was investigated.

The AASC, modified only by TSP (further, the reference AASC), was characterized by initial setting time $-19 \mathrm{~min}$, final setting time $-21 \mathrm{~min}$. The flexural strength / compressive strength of AASC concrete correspond to values of $4.6 / 25.5 \mathrm{MPa}(3 \mathrm{~h}), 5.0$ / $32.3 \mathrm{MPa}(1 \mathrm{~d}), 7.2$ / 66.5 MPa (7 d), 8.7 / 86.8 MPa $(28 \mathrm{~d})$. The $28 \mathrm{~d}$ ratio between tensile strength in bending and compressive strength (further, $R_{\text {bend }} / R_{\text {comp }}$ ) is 0.102 .

The initial setting time can be prolonged up to $60 \mathrm{~min}$ and the final setting time to $70 \mathrm{~min}$ due to modification of the reference AASC by glycerol $(2.70 \%)$. SRA composition "TSP - glycerol" ensures water glass, modified by TSP/GBFS ratio diminution to 0.37 due to plasticizing effect. Insignificant deterioration of modified AASC early strength was fixed. Thus the values of flexural strength / compressive strength are: 3.8 / 19.2 MPa (3 h), 5.0 / 29.5 MPa (1 d). However strength of the modified AASC becomes equal to the reference one in 7 and $28 \mathrm{~d}$. The ratio $R_{\text {bend }} / R_{\text {comp }}$ increases up to 0.140 after $28 \mathrm{~d}$.

Effect of SRA composition "TSP - glycerol polyacrylamide" on properties of AASC was also researched. The content of glycerol was $2.69 \%$ and polyacrylamide $-0.01 \%$. This SRA ensures AASC, characterized by initial setting time $58 \mathrm{~min}$ and final - 66 min while water glass, modified by TSP/GBFS ratio decreases from 0.4 down to 0.38 .

Effects of SRA compositions "TSP - glycerol polyacrylamide" and "TSP - glycerol" on AASC concrete strength are almost similar. Only insignificant deterioration of early strength was fixed. The flexural 
strength / compressive strength of modified AASC concrete corresponds to values of $4.0 / 22.4 \mathrm{MPa}(3 \mathrm{~h})$, 5.4 / $31.8 \mathrm{MPa}$ (1 d), 8.8 / 69.0 MPa (7 h), 13.0 / $85.5 \mathrm{MPa}(28 \mathrm{~d})$. The ratio $\mathrm{R}_{\text {bend }} / \mathrm{R}_{\text {comp }}$ increases up to 0.152 after $28 \mathrm{~d}$. Thus SRA causes maintenance of $\mathrm{R}_{\text {bend }} / \mathrm{R}_{\text {comp }}$ ratio on $37-49 \%$ in comparison with the reference AASC concrete. This is evidence of higher fracture toughness as well as crack resistance during late structure formation [51].

The features of AASC structures, modified by SRA of the mentioned compositions, were investigated by electronic microscopy (Fig. 8, 9, 10).

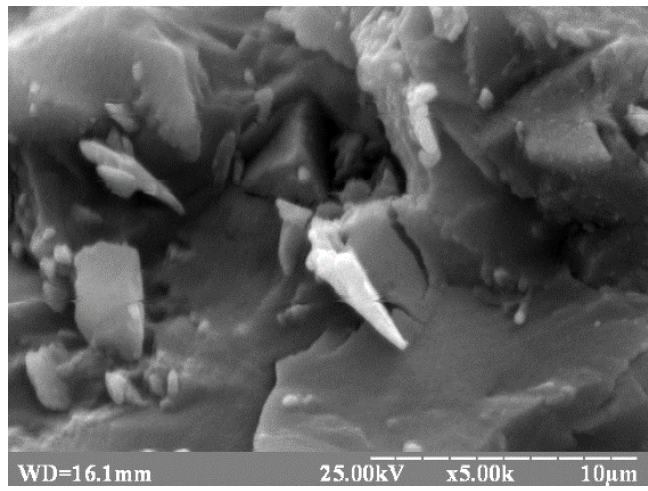

Fig. 8. SEM images of the reference alkali-activated slag cement after $28 \mathrm{~d}$ of hydration.

Unlike to the reference AASC (Fig. 8), SRA "TSP glycerol" ensures increasing volume of hydrates presented by submicrocristalline compounds like spherolites as well as united into agglomerates and block-agglomerates (Fig. 9). SRA composition "TSP glycerol - polyacrylamide" increases depressiveness of hydrated phases and ensures increasing of phase's boundary area in artificial stone (Fig. 10).

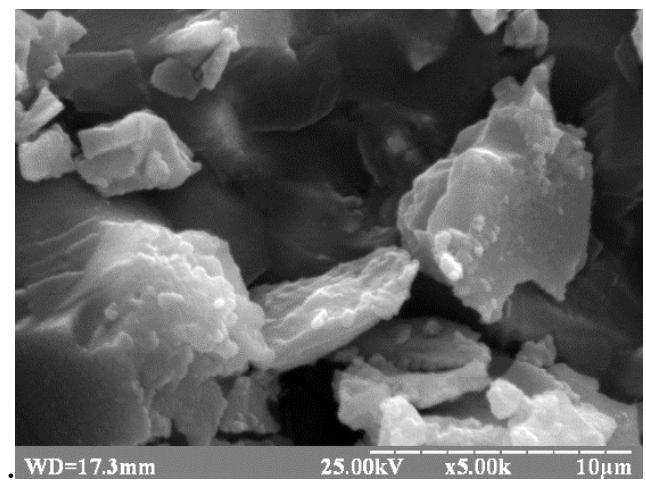

Fig. 9. SEM images of alkali-activated slag cement, modified by shrinkage-reducing admixture composition "trisodium phosphate - glycerol", after $28 \mathrm{~d}$ of hydration.

Specified structures of modified AASC concretes testify their higher ability for relaxation and dissipation of outside energy.

Diagrams of AASC mortars elastic-deformed state in co-ordinates "stress - deformations" are shown on fig. 11, 12, 13. Some increasing of rigidity of AASC concrete, modified by SRA's, during initial load stage was fixed. Increasing of tangent angle for AASC concretes, modified by SRA compositions "TSP - glycerol" and "TSP - glycerol - polyacrylamide", in comparison with the reference AASC concrete from $65^{\circ}$ (Fig. 11) to $66^{\circ}$ (Fig. 12) and $67^{\circ}$ (Fig. 13) agreeably confirm this fact.

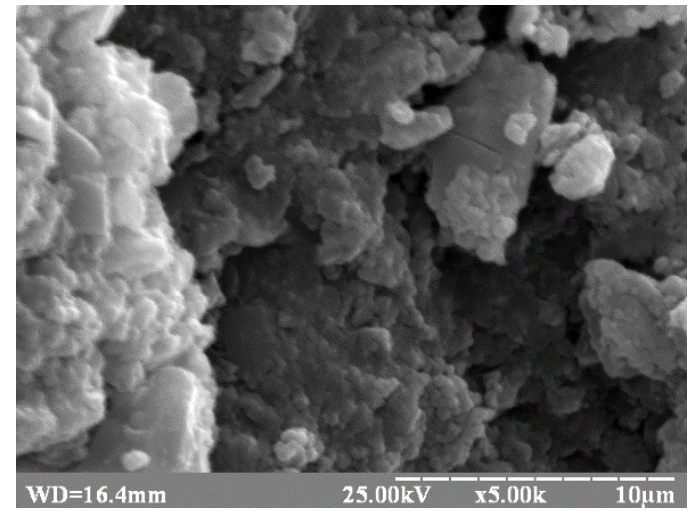

Fig. 10. SEM images of alkali-activated slag cement, modified by shrinkage-reducing admixture composition "trisodium phosphate - glycerol - polyacrylamide", after $28 \mathrm{~d}$ of hydration.

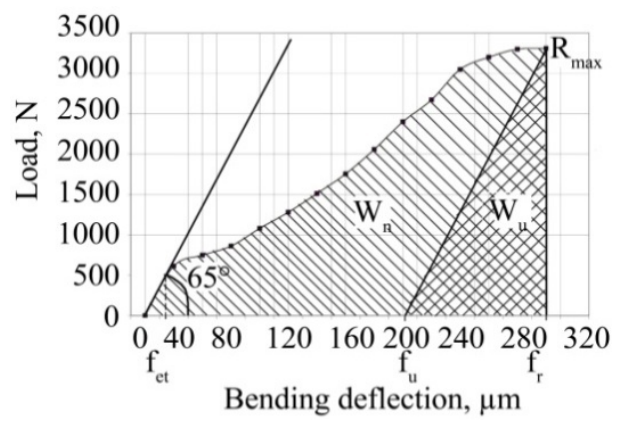

Fig. 11. Deformations of the reference alkali-activated slag cement concrete under load.

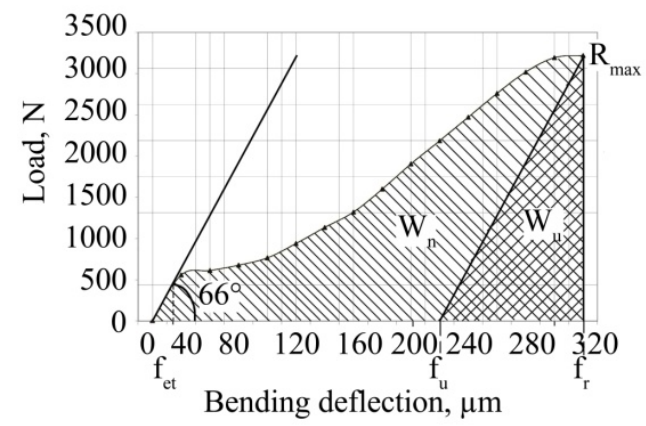

Fig. 12. Deformation of alkali-activated slag cement concrete, modified by shrinkage-reducing admixture composition "trisodium phosphate - glycerol", under load.

SRA ensures higher specific micro cracking (Wn) under subsequent gradual increasing of load until destruction point of samples. Increasing of load resistance for AASC concrete, modified by SRA compositions "TSP - glycerol" and "TSP - glycerol polyacrylamide" from $3310 \mathrm{~N}$ (for the reference AASC concrete) up to $3680 \mathrm{~N}$ and $3720 \mathrm{~N}$ agreeably was fixed. As well AASC concrete, modified by SRA's, can be characterized by increased specific energy of elastic deformation. Increasing in area of sections $W_{u}$ by 39- 
$52 \%$ and maintenance of total bending deflection of samples up to $310 \mu \mathrm{m}$ confirm this fact.

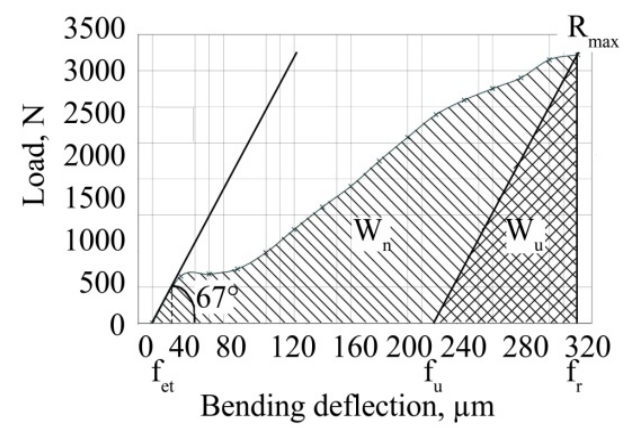

Fig. 13. Deformation of alkali-activated slag cement concrete, modified by shrinkage-reducing admixture composition

"trisodiumphosphate - glycerol - polyacrylamide", under load.

Both mentioned SRA's ensure enhancement of fracture toughness, crack resistance and higher ability to deformation of AASC concretes.

\section{Conclusion}

1. The crack resistance enhancement of alkali-activated slag cement concretes, based on soluble sodium silicates and obtained from high consistency concrete mixes, was shown from initial up to late stages of structure formation. It was realized due to shrinkage-reducing admixtures based on trisodium phosphate and surfactants. This way the higher crack resistance ensures mitigation of steel reinforcement corrosion.

2. Modification of alkali-activated slag cement fine concretes by shrinkage-reducing admixture composition "ordinary portland cement clinker - trisodium phosphate - sodium lignosulphonate - sodium gluconate" causes less drying shrinkage during early age structure formation and mitigation of drying shrinkage from 0,984 to $0,713 \mathrm{~mm} / \mathrm{m}$ after $80 \mathrm{~d}$ as well as enhancement of crack resistance during late structure formation. Effect of shrinkage-reducing admixtures is caused by reduction of water content and increasing crystallinity of AASC hydrates.

3. Shrinkage-reducing admixtures compositions "trisodium phosphate - glycerol" and "trisodium phosphate - glycerol - polyacrylamide" provide fracture toughness enhancement of alkali-activated slag cement fine concretes during late stages of structure formation. As result, the ratio between tensile strength in bending and compressive strength of AASC concrete can be increased up to $37-49 \%$ when water glass is used. At that increasing of bending deflection under load ensures higher elasticity of modified alkali-activated slag cement fine concretes. Specified effects of the shrinkagereducing admixtures are caused by increasing depressiveness of gel-like hydrates, providing redistribution of stresses in artificial stone and thereby advanced fracture toughness under load.

Authors express their gratitude to the Ministry of Education and Science of Ukraine for financial support of the research, that was performed in the framework of budget funding, as well as for the development of the theme of research according to the program of scientific cooperation COST Action CA15202 "Self-Healing concrete: the path to sustainable construction" of the European Union's framework program HORIZON 2020.

\section{References}

1. T. Kropyvnytska, T. Rucinska, H. Ivashchyshyn, R. Kotiv, Development of Eco-Efficient Composite Cements with High Early Strength. Lecture Notes in Civil Engineering 47, 211-218 (2020). doi:10.1007/978-3-030-27011-7_27

2. H. Ivashchyshyn, M. Sanytsky, T. Kropyvnytska, B. Rusyn, Study of low-emission multicomponent cements with a high content of supplementary cementitious materials. Eastern-European Journal of Enterprise Technologies 4(6-100), 39-47 (2019). doi:10.15587/1729-4061.2019.175472

3. T. Markiv, Kh. Sobol, M. Franus, W. Franus, Mechanical and durability properties of concretes incorporating natural zeolite. Archives of Civil and Mechanical Engineering 16, 554-562 (2016). doi:10.1016/j.acme.2016.03.013

4. O. Borziak, S. Chepurna, T. Zidkova, A. Zhyhlo, A. Ismagilov, Use of a highly dispersed chalk additive for the production of concrete for transport structures. MATEC Web of Conf. 230, 03003 (2018). doi:10.1051/matecconf/201823003003

5. J. L. Provis, Geopolymers and other alkali activated materials: why, how, and what?. Mater Struct. 47, 11-25 (2014). doi:10.1617/s11527-013-0211-5

6. J.L. Provis, A. Palomo, C. Shi, Advances in understanding alkali-activated materials. CEMENT CONCRETE RES. 78A, 110-125 (2015). doi:10.1016/j.cemconres.2015.04.013

7. P. Awoyera, A. Adesina, A critical review on application of alkali activated slag as a sustainable composite binder. Case Studies in Construction Materials 11, e00268 (2011). doi:10.1016/j.cscm.2019.e00268

8. V.V. Chistyakov, I.G. Grankovskii, V.I. Gots, Journal of applied chemistry of the USSR 59(3), 542-546 (1986)

9. C.-L. Hwang, M.D. Yehualaw, D.-H. Vo, T.-P. Huynh, Development of high-strength alkaliactivated pastes containing high volumes of waste brick and ceramic powders. Construction and Building Materials 218, 519-529 (2019). doi:10.1016/j.conbuildmat.2019.05.143

10. A. Fernández-Jiménez, J.Y. Pastor, A. Martín, A. Palomo, High-Temperature Resistance in Alkali-Activated Cement. Journal of the American Ceramic Society 93(10), 3411-3417 (2010). doi:10.1111/j.1551-2916.2010.03887.x

11. D. Panias, E. Balomenos, K. Sakkas, The fire resistance of alkali-activated cement-based concrete binders, in Handbook of Alkali-Activated Cements, 
Mortars and Concretes (2015), pp. 423-461. doi:10.1533/9781782422884.3.423

12. Y. Xie, X. Lin, T. Ji, Y. Liang, W. Pan, Comparison of corrosion resistance mechanism between ordinary Portland concrete and alkali-activated concrete subjected to biogenic sulfuric acid attack. Construction and Building Material 228, 117071 (2019). doi:10.1016/j.conbuildmat.2019.117071

13. C. Shi, Corrosion resistance of alkali-activated slag cement. Advances in Cement Research 15(2), 77-81 (2003). doi:10.1680/adcr.2003.15.2.77

14. O. Moskalenko, R. Runova, Ice Formation as an Indicator of Frost-Resistance on the Concrete Containing Slag Cement in Conditions of Freezing and Thawing. Materials Science Forum 865, 145150 (2016) doi:10.4028/www.scientific.net/MSF.865.145

15. M. Cyr, R. Pouhet, The frost resistance of alkaliactivated cement-based binders, in Handbook of Alkali-Activated Cements, Mortars and Concretes (2015), pp. 293-318. doi: $10.1533 / 9781782422884.3 .293$

16. Y. Savchuk, A. Plugin, V. Lyuty, O. Pluhin, O. Borziak, Study of influence of the alkaline component on the physico-mechanical properties of the low clinker and clinkerless waterproof compositions. MATEC Web of Conferences 230, 03018 (2018).

doi:10.1051/matecconf $/ 201823003018$

17. V.D. Glukhovsky et al, Schelochnyie i schelochnoschelochnozemelnyie gidravlicheskie vyazhuschie $i$ betonyi (Alkali-activated and alkaline-alkaline-earth hydraulic binders and concretes). (Vysha shkola, Kyiv, 1979)

18. V.D. Glukhovsky et al, Shlakoschelochnyie betonyi na melkozernistyih zapolnitelyah (Alkalineactivated concretes on fine aggregates). (Vyshcha shkola, Kyiv, 1981)

19. R.F. Runova, Yu.L. Nosovskyi, L.Y. Dvorkin, O.L. Dvorkin, Viazhuchi rechovyny (Binders). (Osnova, Kyiv, 2012)

20. P. Awoyera, A. Adesina, Properties of Alkali Activated Slag Composites: Short Overview. Silicon 12, 987-996 (2020). doi:10.1007/s12633-01900199-1

21. S.A. Bernal, J.L. Provis, Journal of the American Ceramic Society 97(4), 997-1008 (2014)

22. O.A. Mohamed, A Review of Durability and Strength Characteristics of Alkali-Activated Slag Concrete. Materials 12(8), $1198 \quad$ (2019). doi:10.3390/ma12081198

23. H. Ye, A. Radlińska, Effect of Alkalis on Cementitious Materials: Understanding the Relationship between Composition, Structure, and Volume Change Mechanism. Journal of Advanced Concrete Technology 15(4), 165-177 (2017). doi:10.3151/jact.15.165
24. P. Krivenko, V. Gots, O. Petropavlovskyi, I. Rudenko, O. Konstantynovskyi, A. Kovalchuk, Development of solutions concerning regulation of proper deformations in alkali-activated cements. Eastern-European journal of Enterprise Technologies 5(6-101), 24-32 (2019). doi:10.15587/1729-4061.2019.181150

25. P.A. Rebinder, Ye.Ye. Segalova, Ya.A. Amelina, Fiziko-himicheskie osnovyi gidratatsionnogo tverdeniya vyazhuschih veschestv (Phisicalchemical foundations of binders hydration hardening), in VI international congress on cement chemistry, book 1, vol. 2 (Stroyizdat, Moscow, 1976), pp. 58-64

26. Y. Turba, S. Solodkyy, T. Markiv, Strength and Fracture Toughness of Cement Concrete, Dispersedly Reinforced by Combination of Polypropylene Fibers of Two Types. Lecture Notes in Civil Engineering 47, 488-494 (2020). doi:10.1007/978-3-030-27011-7_62

27. R.F. Runova, V.I. Gots, I.I. Rudenko, O.P. Konstantynovskyi, O.V. Lastivka, The efficiency of plasticizing surfactants in alkali-activated cement mortars and concretes. MATEC Web of Conferences 230, $03016 \quad$ (2018). doi:10.1051/matecconf/201823003016

28. I. Rudenko, O. Konstantynovskyi, A. Kovalchuk, M. Nikolainko, D. Obremsky, Efficiency of redispersible polymer powders in mortars for anchoring application based on alkali activated Portland cements. Key Engineering Materials 761, 27-30 (2018). doi:10.4028/www.scientific.net/KEM.761.27

29. M. Palacios, Y.F. Houst, P. Bowen, F. Puertas, Adsorption of superplasticizer admixtures on alkaliactivated slag pastes. Cement and Concrete Research 39(8), 670-677 (2009). doi:10.1016/j.cemconres.2009.05.005

30. M. Najimi, N. Ghafoori, M. Sharbaf, Alkaliactivated natural pozzolan/slag binders: limitations and remediation. Magazine of Concrete Research, 1-48 (2019). doi:10.1680/jmacr.18.00184

31. Korneev V., Danilov V., Zhidkoe $i$ rastvorimoe steklo (Water and Soluble Glass). (Stroyizdat, SaintPetersburg, 1996)

32. E.F. Kudina, G.G. Pechersky, O.A. Ermolovich, Issledovanie protsessa geleobrazovaniya $\mathrm{v}$ sistemah zhidkoe steklo-akrilamid (Investigation of gel formation in systems of water grass-polyakrylamid). Plasticheskie massy 1, 27-29 (2012)

33. I.N. Tikhomirova, T.V. Skorina, The influence of silicate modulus of water glass on properties of cementitious materials. Stroitelnye materialy 12, 72-74 (2009)

34. K. Chen, C.-H. Yang, Z.-D. Yu, Effect of admixture on drying shrinkage of alkali-activated slag mortar. Journal of Chongqing University 34(1), 38-40 (2011) 
35. V. Bílek, L. Pařízek, P. Kosár, J. Kratochvíl, L. Kalina, Materials Science Forum 851, 45-50 (2016)

36. V. Bilek, L Kalina, H. Simonova, Effect of curing environment on length changes of alkali-activated slag/cement kiln by-pass dust mixtures. IOP Conference Series: Materials Science and Engineering 583, 012017 (2019). doi:10.1088/1757$899 X / 583 / 1 / 012017$

37. L. Kalina, V. Bílek, R. Novotný, M. Mončeková, J. Másilko, J. Koplík, Effect of $\mathrm{Na}_{3} \mathrm{PO}_{4}$ on the Hydration Process of Alkali-Activated Blast Furnace Slag. Materials 9(5), 395 (2016). doi:10.3390/ma9050395

38. L. Kalina, V. Bílek, K. Komosná, R. Novotný, J. Tkacz, Effect of Phosphates on the Hydration Process of Alkali Activated Materials. Materials Science Forum 851, 63-68 (2016). doi:10.4028/www.scientific.net/MSF.851.63

39. F. Pacheco-Torgal, J. Barroso de Aguirre, Y. Ding, W. Tahri, S. Baklouti, Handbook of Alkali-activated Cements, Mortars and Concretes, 1st edn. (Elsevier, 2015), pp. 627-642

40. L. Sail, F. Ghomari, A. Khelidj, A. Bezzar, O. Benali, The effect of phosphate corrosion inhibitor on steel in synthetic concrete solutions. Advances in materials Research 2(3), 155-172 (2013). doi:10.12989/amr.2013.2.3.155

41. S. Rajendran, Int J Nano Corr Sci and Engg. 3(4), 216-222 (2016)

42. S.D. Meenakshi, S. Rajendran, J. Sathiyabama, R.J. Rathish, Int J Nano Corr Sci and Engg. 4(2), 1-25 (2017)

43. J. Zhang, X. Lu, J. Zhang, L. Zhang, C. Zhu, Y. Zhang, T. Wu, Corrosion-Inhibition Effect of Different Phosphate Compounds for Carbon Steel in Chloride-Contaminated Mortars. Int. J. Electrochem. Sci. 14, 8601-8610 (2019). doi: $10.20964 / 2019.09 .29$

44. D.M. Bastidas, M. Criado, S. Fajardo, A. La Iglesia, J.M. Bastidas, Corrosion inhibition mechanism of phosphates for early-age reinforced mortar in the presence of chlorides. Cement \& Concrete Composites 61, 1-6 (2015). doi:10.1016/j.cemconcomp.2015.04.009

45. S.V. Samchenko, Formirovanie i genezis struktury tsementnogo kamnya (Formation and genesys of cement stone structure). (NIU MGSU, Moskva, 2016)

46. A.G. Gelevera, Dissertation, Kyiv, 1986

47. J. Yang, Q. Wang, Y. Zhou, Influence of Curing Time on the Drying Shrinkage of Concretes with Different Binders and Water-to-Binder Ratios. Advances in Materials Science and Engineering 2017, 1-10 (2017). doi:10.1155/2017/2695435

48. Z. Jia, Y. Yang, L. Yang, Y. Zhang, Z. Sun, Construction and Building Materials 158, 198-207 (2018). doi:10.1016/j.conbuildmat.2017.09.162
49. P. Krivenko, O. Petropavlovskyi, I. Rudenko, O. Konstantynovskyi, A. Kovalchuk, Alkali-activated Portland cement with adjustable proper deformations for anchoring application. IOP Conference Series: Materials Science and Engineering (MSE) 708, $012090 \quad$ (2019). doi:10.1088/1757-899X/708/1/012090

50. P. Krivenko, O. Petropavlovskyi, I. Rudenko, O. Konstantynovskyi, The influence of complex additive on strength and proper deformations of alkali-activated slag cements. Materials Science
Forum
968,
13-19
(2019). doi:10.4028/www.scientific.net/MSF.968.13

51. D.M. Korotkhih, Dissertation, Voronezh, 2014 